\title{
Gestational Trophoblastic Tumor Pathologic Distant Metastasis TNM Finding $\mathrm{v} 7$
}

National Cancer Institute

\section{Source}

National Cancer Institute. Gestational Trophoblastic Tumor Pathologic Distant

Metastasis TNM Finding v7. NCI Thesaurus. Code C89700.

A pathologic finding about one or more characteristics of gestational trophoblastic tumor, following the rules of the TNM AJCC V7 classification system as they pertain to distant metastases. There is no pathologic M0 for gestational trophoblastic tumor. 